MATRIK: JURNAL MANAJEMEN, STRATEGI BISNIS DAN KEWIRAUSAHAAN

Homepage: https://ojs.unud.ac.id/index.php/imbk/index

Vol. 15 No. 2, Agustus (2021), 265-275

\title{
Pemanfaatan Media Sosial Untuk Wirausahawan Wanita Di Masa Pandemi Covid-19: Studi Literatur Sistematis
}

Finnah Fourqoniah"1), Muhamad Fikry Aransyah ${ }^{2 * *}$

${ }^{1,2}$ Universitas Mulawarman

email: fikry.aransyah@gmail.com

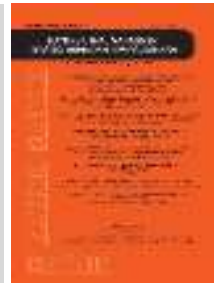

DOI : https://doi.org/10.24843/MATRIK:JMBK.2021.v15.i02.p9

\begin{abstract}
ABSTRAK
Womenpreneurs adalah seorang pengusaha wanita yang dapat mengatur atau mengelola perusahaan atau bisnis. Dalam menjalankan bisnis harus memiliki strategi agar dapat bertahan dalam segala kondisi dan memiliki ketahanan bisnis yang kuat, terutama pada saat pandemi Covid-19 seperti saat ini. Salah satu strateginya adalah dengan memanfaatkan media sosial sebagai wadah untuk terus mengembangkan omzet penjualan. Penelitian ini bertujuan untuk menggali data dan informasi terkait penggunaan media sosial bagi wanita yang memiliki usaha pada saat pandemi Covid-19. Penelitian ini menggunakan metode Systematic Literature Review. Jumlah artikel yang ditemukan sebanyak 10 artikel yang kemudian dikelompokkan berdasarkan konsep dan pembahasan yang sama dengan topik yang diangkat. Hasil dari penelitian ini adalah media sosial sangat bermanfaat untuk meningkatkan omset penjualan pada saat pandemi Covid-19.
\end{abstract}

Kata kunci: bisnis, media sosial, daya tahan, womenpreneurs

Utilization Of Social Media For Womenpreneurs In The Time Of The Covid-19 Pandemic: A Systematic Literature Review

\begin{abstract}
Womenpreneurs is a woman entrepreneur who can organize or manage a company or business. In carrying out a business, they must have a strategy to be able to survive in all conditions and have a strong business resilience, especially during the current Covid-19 pandemic. One strategy is to use social media as a forum to continue to develop sales turnover. This study aims to explore data and information related to the use of social media for women who have businesses during the Covid-19 pandemic. This study uses the Systematic Literature Review method. The number of articles found was as many as 10 articles which were then grouped based on the same concepts and discussions as the topics raised. The result of this study is that social media is very useful for increasing sales turnover during the Covid-19 pandemic.
\end{abstract}

Keyword: business, social media, endurance, womenpreneurs

\section{PENDAHULUAN}

Perempuan dalam kenyataannya dapat menjadi pelaku utama dalam bidang ekonomi, dan hal tersebut sangat potensial dalam bisnis usaha mikro. Hal ini disebabkan oleh beberapa sifat alamiah perempuan seperti telaten maupun lebih teliti dalam melakukan segala hal selain itu perempuan lebih mudah bergaul dengan orang lain sehingga lebih mudah untuk menjaring pelanggan (Astuti et al., 2020). Di sisi lain perempuan lebih jeli melihat peluang usaha yang sering kali peluang usaha yang dianggap sepele oleh kaum laki-laki. Keunggulan-keunggulan tersebutlah yang dapat dijadikan modal dasar perempuan untuk terus memberdayakan dan 
mengembangkan potensi-potensi di bidang kewirausahaan (Astuti et al., 2020). Namun situasi saat ini sepertinya tidak memungkinkan bagi para wirausahawan perempuan untuk terus mengembangkan potensi tersebut (Awali \& Rohmah, 2020), salah satu keadaan yang membuat usaha dan beberapa sektor bisnis mengalami penurunan pendapatan yang substansial yakni adanya pandemic yang disebabkan oleh virus Corona (Covid-19).

Pandemic Covid-19 memiliki dampak besar terhadap keberlangsungan bisnis besar maupun UMKM. Rata-rata pelaku usaha mengalami ketidakpastian hasil atau pendapatan yang diperoleh saat musim pandemic. Penurunan pendapatan dan bahkan puluhan hingga ratusan pelaku usaha utamanya UMKM telah menutup usahanya karena penetapan kebijakan Pembatasan Sosial Berskala Besar yang mengharuskan pekerja menjadi work from home, penutupan instansi pelayanan public serta kebijakan social distance. Namun, meski pandemic Covid-19 memunculkan beberapa masalah di sektor kewirausahaan, teknologi informasi dan komunikasi dapat menjadi rencana paling solutif untuk mempertahankan bisnis dikarenakan total e-commerce pada 2020 mencapai hingga USD\$ 130 miliar (Soetjipto, 2020).Salah satu pemanfaatan teknologi informasi dan komunikasi dengan pemanfaatan media sosial sebagai wadah untuk berdagang. Para pelaku bisnis diharuskan untuk melek terhadap teknologi demi mempertahankan usahanya (Awali \& Rohmah, 2020).

Era digital sekaligus keadaan pandemi saat ini bisa menjadi dorongan wirausahawan perempuan untuk tetap bisa mengembangkan bisnis dan usahanya yang dapat dipasarkan secara online. Ada banyak keuntungan dari pemasaran bisnis melalui online, salah satunya penyaluran informasi kepada konsumen lebih mudah dan praktis sekaligus konsumen juga dapat menerima informasi secara cepat dan tepat atas barang ataupun jasa yang dibutuhkan. Dengan kondisi dimana masyarakat harus membatasi mobilisasi dan juga sosial distance, proses bisnis tetap berjalan dengan harapan mengembalikan kegiatan jual-beli yang sempat berkurang intensitasnya dikarenakan dampak dari persebaran penyakit Covid-19 di Indonesia (Awali \& Rohmah, 2020)

Selaras dengan hal tersebut penelitian (Joesyiana, 2019) menyatakan bahwa 75\% responden telah mengambarkan informasi mengenai produk atau jasa yang dijual dengan baik. Melalui deskripsi informasi produk secara lengkap maka konsumen akan mengetahui informasi yang diperlukan. Dampaknya kemudian juga meningkatkan kepercayaan konsumen terhadap produk tersebut (Joesyiana, 2019).

\section{METODE PENELITIAN}

Metode penelitian yang digunakan ialah system literature review (SLR) yakni sebuah metode penelitian yang digunakan dengan cara mereview dan merangkum hasil-hasil penelitian yang telah dilakukan (penelitian primer) untuk menyajikan fakta yang lebih komplit (Siswanto, 2012). Berdasarkan data pencarian menggunakan kata kunci dan kriteria di database di atas, maka dapat dikelompokkan menjadi 15 jurnal yang dapat dijadikan acuan untuk penulisan penelitian ini. Langkah-langkah yang digunakan untuk penelitian menggunakan SLR ini adalah sebagai berikut (Anugraheni et al., 2020):

a. Menentukan topik penelitian yang akan dilakukan terkait fenomena di dunia wirausaha, minat peneliti yakni "Pemanfaatan Media Sosial untuk Wirausahawan Wanita di Masa Pandemi Covid-19"

b. Menentukan kata kunci yang digunakan untuk mencari penelitian primer atau literatur, yakni: womenpreneurs in social media, womenpreneurs social media, wirausahawan wanita menggunakan social media, wirausahawan di kala pandemi Covid-19.

c. Mencari artikel terkait kata kunci yang telah ditentukan, baik atriket nasional maupun internasional. Adapun jumlah artikel yang dibutuhkan adalah sebanyak mungkin, namun tetap relevan dengan tujuan penelitian ini. 
d. Artikel yang terkumpul yakni 15 artikel kemudian masuk ke tahap seleksi terkait kesesuaian dengan topik penelitian. Hasil dari seleksi didapatkan ada 10 artikel yang relevan.

e. Artikel yang telah lolos seleksi akan di review satu persatu.

f. Membuat peta konsep dari 15 artikel yang telah di review berupa tabel anteseden yang memuat informasi terkait pemberdayaan wirausahawan wanita dengan media sosial, baik terkait cara pemberdayaannya hingga manfaat media sosial untuk wirausahawan tersebut.

g. Mulai Menyusun artikel berdasarkan literatur yang telah didapatkan.

\section{HASIL DAN PEMBAHASAN}

Media sosial merupakan kegiatan komunikasi dua arah dalam penyampaian informasi yang dapat menyebar secara otomatis (Kusumadewi, 2020). Media sosial bersifat dinamis, tidak terikat oleh jarak dan waktu. Dalam hal ini komunikasi antar manusia dapat terjalin walaupun dengan jarak yang sangat jauh (Nordiana, 2014 dalam (Kusumadewi, 2020).

Womenpreneurs merupakan seorang pengusaha wanita yang dapat mengatur maupun mengelola suatu perusahaan atau bisnis. Jadi womenpreneurs yakni wanita pengusaha yang memiliki keterampilan sehingga menjadikan kreatif dan inovatif sebagai sumber utama atau sumber dasar, sumber daya, tenaga penggerak, tujuan maupun kiat dan juga proses dalam menjalankan suatu bisnis (Novialumi et al., 2020). Womenpreneurs melakukan usaha online menggunakan media sosial seperti instagram, whatsapp, twitter, facebook dan masih banyak media online yang dapat digunakan untuk melakukan usaha online.

\section{Tabel 1. Literatur yang digunakan}

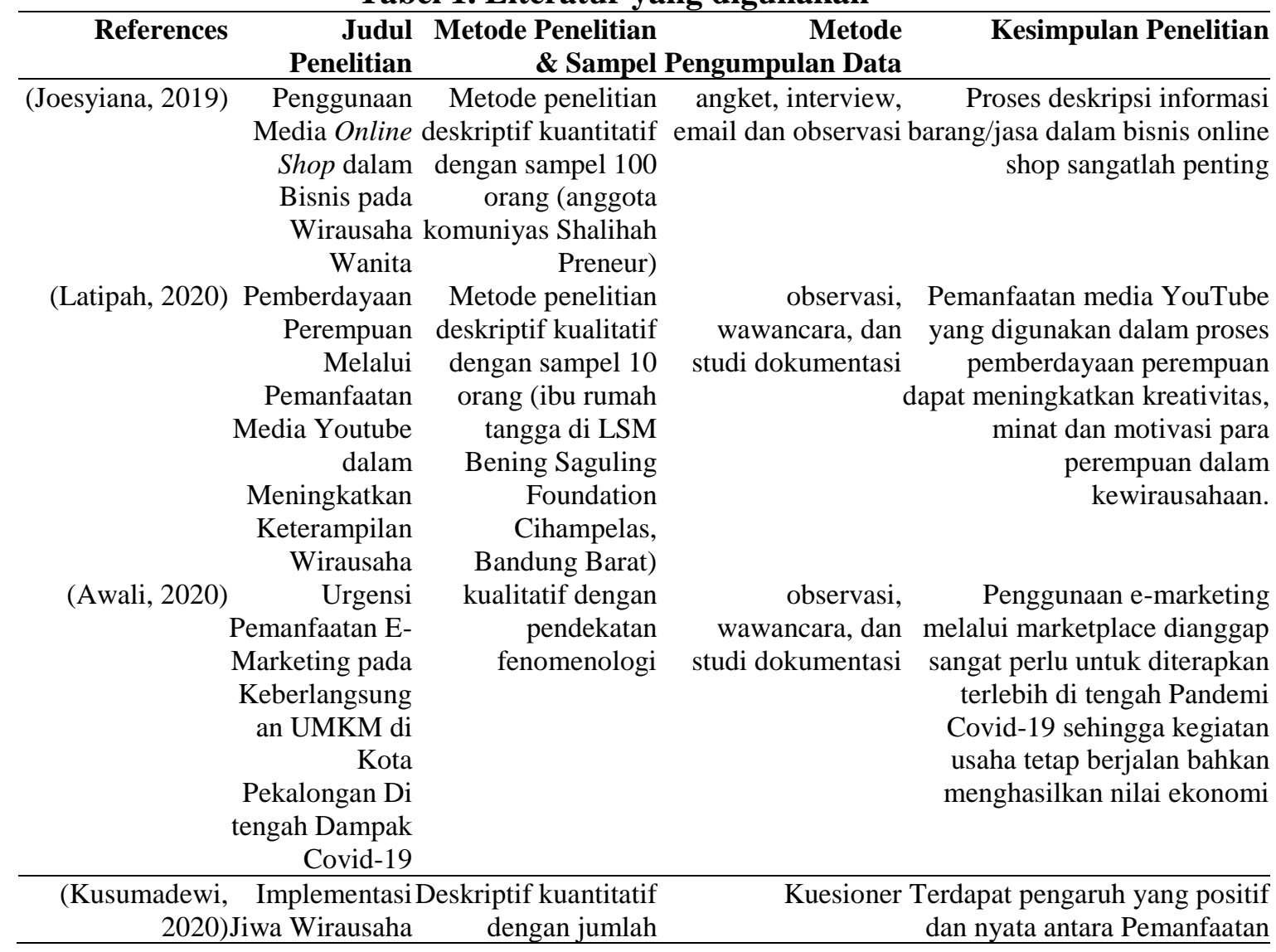




\begin{tabular}{|c|c|c|c|c|}
\hline & $\begin{array}{r}\text { dan } \\
\text { Pemanfaatan } \\
\text { Media Sosial } \\
\text { terhadap Minat } \\
\text { Berwirausaha } \\
\text { pada } \\
\text { Mahasiswa } \\
\text { Purwakarta }\end{array}$ & $\begin{array}{r}\text { sampel yakni } 95 \\
\text { responden dengan } \\
\text { penjabaran. }\end{array}$ & & $\begin{array}{r}\text { Media Sosial terhadap Minat } \\
\text { Berwirausaha }\end{array}$ \\
\hline $\begin{array}{r}\text { (Isyfi'afiani, } \\
2018)\end{array}$ & $\begin{array}{r}\text { Advancing } \\
\text { Women's } \\
\text { Digital Skill } \\
\text { and Economic } \\
\text { Empowerment } \\
\text { through Girls } \\
\text { in Tech } \\
\text { Indonesia: A } \\
\text { Case Study }\end{array}$ & $\begin{array}{r}\text { Penelitian kualitatif } \\
\text { dengan informan } \\
\text { terbagi menjadi } 2 \\
\text { grup dan terdapat } 4 \\
\text { kriteria responden } \\
\text { sehingga jumlah } \\
\text { sampel yang } \\
\text { didapatkan adalah } 5 \\
\text { informan. }\end{array}$ & In-depth Interviews & $\begin{array}{r}\text { Womenpreneur } \\
\text { Akselerasi Digital, Girl in Tech } \\
\text { Indonesia berhasil } \\
\text { menerapkan transformasional } \\
\text { kinerja kepemimpinan yang } \\
\text { berdampak } \\
\text { secara positif terhadap ekonomi } \\
\text { perempuan } \\
\text { pemberdayaan melalui } \\
\text { penguasaan Teknologi } \\
\text { Informasi dan Komunikasi }\end{array}$ \\
\hline $\begin{array}{r}\text { (Novialumi, } \\
\text { Anita., 2020) }\end{array}$ & $\begin{array}{r}\text { Perkembangan } \\
\text { Media Sosial } \\
\text { dalam Merubah } \\
\text { Perilaku } \\
\text { Women } \\
\text { Entrepreneursh } \\
\text { ip di Kota } \\
\text { Bekasi } \\
\end{array}$ & Kualitatif deskriptif & $\begin{array}{r}\text { Observasi dan in- } \\
\text { depth interview }\end{array}$ & $\begin{array}{r}\text { Woman Entrepreneurship } \\
v \text { menggunakan aplikasi internet } \\
\text { dalam memasarkan dan } \\
\text { mencari informasi bisnisnya, } \\
\text { sehingga aplikasi internet } \\
\text { dalam media sosial sangat } \\
\text { membantu dalam berwirausaha } \\
\text { para women entrepreneurship }\end{array}$ \\
\hline $\begin{array}{r}\text { (Lucky and } \\
\text { Rosmadi, 2021) }\end{array}$ & $\begin{array}{r}\text { Penerapan } \\
\text { Strategi Bisnis } \\
\text { di Masa } \\
\text { Pandemi } \\
\text { Covid-19 }\end{array}$ & $\begin{array}{r}\text { metode kualitatif } \\
\text { dengan pendekatan } \\
\text { deskriptif }\end{array}$ & $\begin{array}{l}\text { wawancara yang } \\
\text { tidak terstruktur }\end{array}$ & $\begin{array}{r}\text { Peran pemerintah dan } \\
\mathrm{r} \\
\text { perbankan sangat penting } \\
\text { terutama berkaitan dengan } \\
\text { pelatihan dalam penggunaan } \\
\text { teknologi informasi agar } \\
\text { produk usaha kecil tetap dapat } \\
\text { bertahan di tengah pandemi } \\
\text { covid-19 }\end{array}$ \\
\hline $\begin{array}{r}\text { (Hardilawati, } \\
2020)\end{array}$ & $\begin{array}{r}\text { Strategi } \\
\text { Bertahan } \\
\text { UMKM di } \\
\text { Tengah } \\
\text { Pandemi } \\
\text { Covid-19 }\end{array}$ & $\begin{array}{r}\text { analisis kualitatif } \\
\text { dengan langkah } \\
\text { eksploratif }\end{array}$ & $\begin{array}{r}\text { Observasi } \\
\text { Partisipatif }\end{array}$ & $\begin{array}{r}\text { i } \\
\text { f } \\
\text { berwirategi bertahan dalam } \\
\text { Covid yakni melakukan } \\
\text { penjualan melalui e-commerce } \\
\text { karena masyarakat lebih } \\
\text { memilih belanja secara online } \\
\text { sekaligus melakukan } \\
\text { pemasaran produk dengan } \\
\text { memanfaatkan teknologi digital } \\
\text { untuk menjangkau lebih } \\
\text { banyak konsumen. }\end{array}$ \\
\hline $\begin{array}{r}\text { (Khasanah, } \\
\text { Samsiana and } \\
\text { Handayanto, } \\
2020)\end{array}$ & $\begin{array}{r}\text { Pemanfaatan } \\
\text { Media Sosial } \\
\text { dan } E- \\
\text { commerce } \\
\text { Sebagai Media } \\
\text { Pemasaran } \\
\text { Dalam } \\
\text { Mendukung } \\
\text { Peluang Usaha } \\
\text { Mandiri Pada } \\
\text { Masa Pandemi } \\
\text { Covid } 19\end{array}$ & $\begin{array}{r}\text { Pengabdian } \\
\text { Masyarakat dengan } \\
\text { sampel sekelompok } \\
\text { orang tua komite } \\
\text { salah satu sekolah } \\
\text { dasar swasta di } \\
\text { Bekasi }\end{array}$ & Pelatihan & $\begin{array}{r}\text { Hasil penelitian ini didapatkan } \\
\text { bahwa para responden } \\
\text { mendapatkan nilai tinggi yakni } \\
\text { sebesar } 4,5 \text { terkait pemanfaatan } \\
\text { media sosial dan e-commerce } \\
\text { sehingga terbukti bahwa hal } \\
\text { tersebut dapat menunjang para } \\
\text { pelaku usaha untuk tetap } \\
\text { mendapatkan omset di masa } \\
\text { pandemic Covid-19 }\end{array}$ \\
\hline
\end{tabular}


Telah diketahui bahwa pada tahun 2020, di beberapa negara di dunia mengalami sebuah pandemic, yakni musibah akibat tersebar luasnya virus Corona (Covid 19) yang mana semua negara segera mengambil upaya perbaikan maupun upaya preventif seperti social distance, work from home, menutup semua sektor pelayanan publik. Tentunya kebijakan tersebut memiliki dampak besar terhadap keberlangsungan bisnis. Baik itu bisnis besar maupun UMKM. Menurut hasil survey, terdapat 96\% pelaku usaha mengalami dampak negatif pandemic tersebut terhadap proses bisnisnya (Sebanyak 1.785 koperasi dan 163.713 pelaku usaha mikro kecil menengah). Sebanyak $75 \%$ mengalami penurunan penjualan yang substansial (Soetjipto, 2020).

Indonesia adalah negara di mana ekonominya terdiri dari sebagian besar kegiatan kewirausahaan yang mencakup beberapa usaha kecil dan besar, menurut (Anggadwita \& Dhewanto, 2016). Telah dinilai bahwa masyarakat Indonesia percaya untuk memiliki wirausaha dan menunjukkan kinerja yang lebih baik dalam bisnis untuk mencapai kesuksesan dalam pertumbuhan ekonomi dan kemakmuran dalam perekonomian negara. Oleh karena itu, sebagaimana dimaksud dalam studi (Effendi \& Suryana, 2019), masyarakat terdorong untuk mengembangkan kegiatan usaha baru dan mendapatkan hasil yang maksimal dari usaha tersebut. (Anggadwita \& Dhewanto, 2016) menambahkan bahwa di antara para pengusaha ini, Indonesia memiliki sejumlah besar pengusaha perempuan di negara ini yang menjalankan banyak usaha kecil dan besar untuk kemakmuran dan pertumbuhan negara. Studi (Setini et al., 2020) menjelaskan bahwa perempuan di Indonesia mencapai hingga 45\% dari bisnis di Indonesia di antara angkatan kerja. Meskipun perempuan memiliki pendidikan yang lebih rendah daripada laki-laki, mereka mewakili $49 \%$ dari angkatan kerja di negara ini, seperti yang dibahas dalam studi (Anggadwita \& Dhewanto, 2016). Hasil penelitian menunjukkan bahwa $90 \%$ perempuan di Indonesia termasuk mereka yang bersembunyi dan mengetahui beberapa bisnis merupakan bagian dari beberapa kegiatan kewirausahaan yang membuat sebagian besar perempuan terlibat dalam bisnis tersebut (Suyuthi et al., 2019). Menurut (Anggadwita \& Dhewanto, 2016), perempuan di tanah air diberikan hak yang sama, dan sarana kewirausahaan mendukung mereka dan telah menciptakan sarana bisnis di antara mereka.

Studi (Orser et al., 2019) menyoroti bahwa perempuan di Indonesia telah memainkan peran penting dalam mengembangkan kegiatan wirausaha yang lebih baik dan menunjukkan respons positif terhadap perekonomian negara. Oleh karena itu, penelitian berikut ini bertujuan untuk menilai dampak pendidikan dan pelatihan terhadap kinerja mereka yang dapat secara efektif meningkatkan kinerja mereka dan memoles karakteristik mereka untuk kegiatan yang lebih baik di masa depan (Jha et al., 2018). Alasan di balik penelitian ini adalah untuk menilai isu kebijakan pendidikan dan pelatihan yang lebih rendah bagi perempuan di Indonesia yang telah mempengaruhi kinerja perempuan Indonesia.

Tinjauan literatur tentang kewirausahaan dan pengembangan menunjukkan bahwa banyak peneliti telah berfokus pada pemeriksaan isu-isu seperti gender, dengan lebih menekankan pada perempuan. Khususnya, hanya sedikit penelitian yang mengeksplorasi berbagai aspek kewirausahaan laki-laki. Akibatnya, analisis komparatif antara kewirausahaan perempuan dan laki-laki terbatas pada evaluasi bukti mengenai gender dalam motivasi dan kendala kewirausahaan. Dalam studi ini, telah ditetapkan bahwa kewirausahaan perempuan di Indonesia merupakan pilar penting yang mendukung pertumbuhan ekonomi negara dan merupakan sumber lapangan kerja yang substansial bagi banyak pemuda. Data yang ada menunjukkan bahwa jumlah perempuan pengusaha yang mendirikan dan mengelola usaha semakin meningkat. Namun, para wanita inovatif ini masih menghadapi hambatan khusus yang membatasi kemampuan mereka untuk bersaing secara menguntungkan dengan rekan- 
rekan pria mereka. Secara khusus, budaya dan tingkat pendidikan yang rendah adalah beberapa faktor yang menghambat sebagian besar perempuan Indonesia untuk memulai dan menjalankan bisnis. Sangat penting untuk menyoroti bahwa Indonesia pada dasarnya adalah masyarakat patriarki. Banyak orang Indonesia yang percaya bahwa peran perempuan adalah mengurus keluarga dan mengatur kegiatan rumah tangga. Oleh karena itu, ketika seorang perempuan memiliki atau mengelola perusahaan bisnis, sebagian besar penduduk setempat tampaknya mempertanyakan kemampuannya untuk menyeimbangkan tanggung jawab pekerjaan dan keluarga.

\section{Pemanfaatan Media Sosial untuk Womenpreneurs}

Telah diketahui bahwa berwirausaha menggunakan media online merupakan salah satu cara untuk mengembangkan karir dan strategi bisnis yang baik. Adapun beberapa platform atau media sosial yang dapat digunakan untuk tempat menawarkan barang maupun jara para wirausahawan wanita seperti Instagram, facebook dan lainnya. Namun, womenpreneurs juga harus memahami bagaimana alur proses transaksi bisnis melalui online (Lubis, 2019). Menurut (Joesyiana, 2019) alur dari sebuah proses transaksi bisnis online shop harus bisa diukur maupun digambarkan sedemikian rupa, hal ini bertujuan agar kegiatan atau usaha yang dijalankan sesuai dengan strategi yang telah ditetapkan di awal. Menurut (Joesyiana, 2019) pebisnis perempuan yang berjualan online banyak menggunakan media online shop seperti instagram, twitter, facebook dan youtube. Media sosial yang paling banyak di pilih oleh responden dalam memasarkan produk mereka adalah instagram. Di karenakan pengguna instagram di Indonesia yang dari tahun ke tahun terus bertambah. Pana penelitian (Joesyiana, 2019) alur dibuat lebih simple yang mencakup saat bisnis tersebut pertama kali dijalankan sampai saat produk/jasa yang ditawarkan terjual hingga ke tangan konsumen. Adapun gambaran alur proses jual beli dalam bisnis online shop sebagai berikut:

Gambar 1. Proses Jual Beli Online Shop

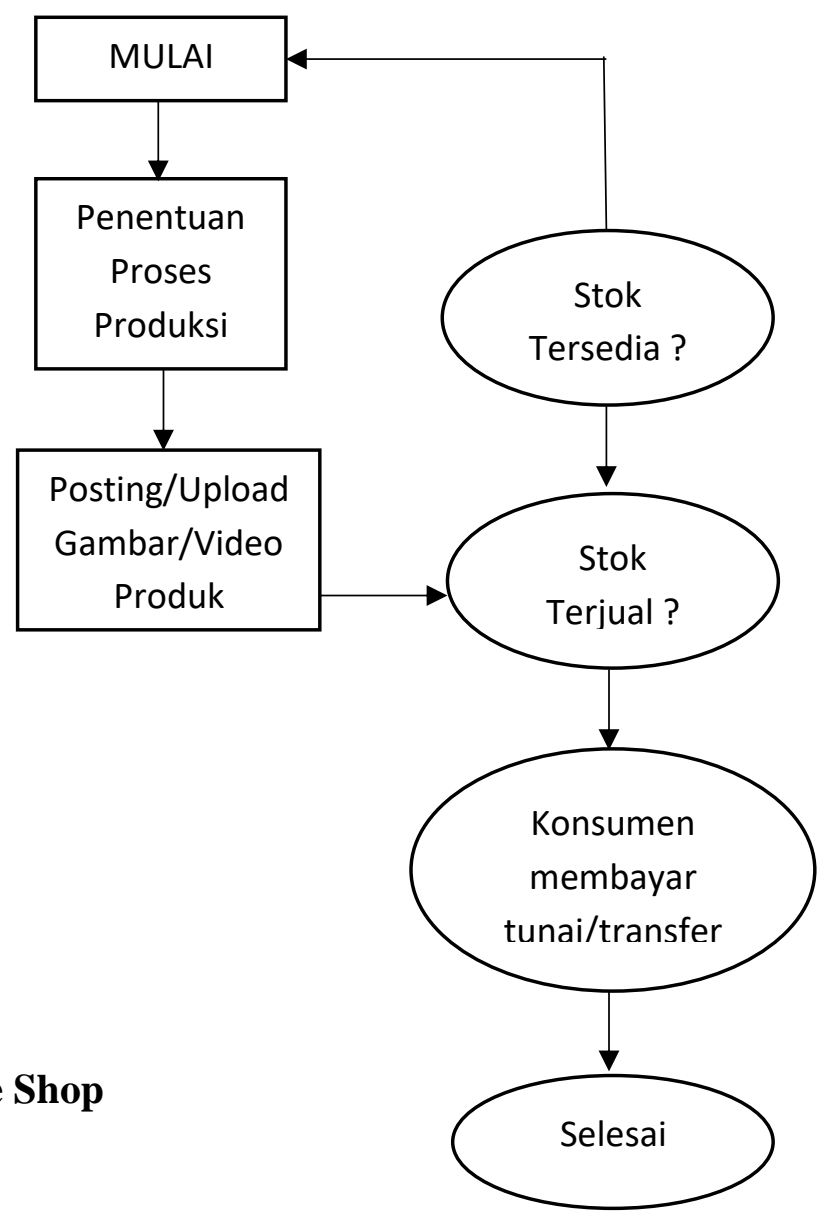


Sumber: Joesyiana, 2019

Berdasarkan gambar diatas dapat diketahui bahwa bisnis menggunakan media sosial atau bisnis online dimulai dengan menetapkan proses produksinya, apakah ingin memproduksi sendiri atau hanya sebagai penjual dalam arti tangan ke 2. Lalu kemudian hal yang harus dilakukan yakni memilih sosial media yang digunakan untuk mengupload barang/jasa yang akan dijual. Berikut adalah 10 media sosial yang sering digunakan pada tahun 2020.

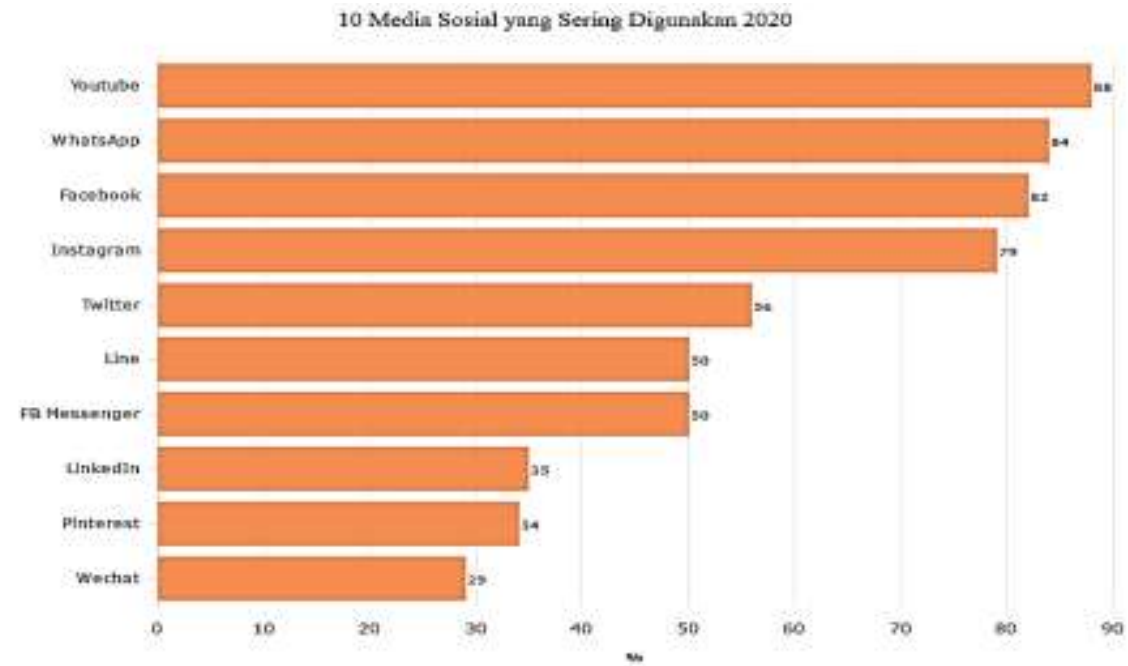

Gambar 2. 10 Media Sosial yang Sering Digunakan 2020

Sumber: We Are Social, Hootsuite, 2020 ((Jayani, 2020) dalam databooks.katadata.co.id)

Berdasarkan Gambar.2 dapat diketahui bahwa Youtube menduduki peringkat pertama untuk media sosial yang sering digunakan, disusul oleh whatsapp, selanjutnya facebook, dan urutan ke empat yakni Instagram. Dari data tersebut, womenpreneurs bisa menentukan media sosial yang tepat untuk memasarkan produknya. Untuk media sosial youtube sejalan dengan sebuah penelitian yang dicetuskan oleh (Latipah, 2020) yang mana hasil penelitiannya yakni responden dalam penelitian tersebut dapat menguasai materi wirausaha melalui media youtube, bahkan para responden juga berhasil mengakses maupun mengunduh beberapa video yang ada di youtube, selain itu responden juga mengetahui cara agar menghasilkan produk yang bernilai jual, mengelola usaha-usaha mikro dan mengelola keuangan dalam berbisnis. Dengan demikian pemberdayaan yang dilakukan terkait media sosial berjalan dengan efektif dan efisien serta para responden juga memiliki penghasilan tambahan dari hasil penjualan produk yang telah dijualnya.

Langkah selanjutnya dari proses penjualan dengan media sosial yakni menetapkan produk yang akan dijual. Jika produk yang akan dipasarkan telah didapatkan, maka Langkah selanjutnya adalah memposting produk-produk tersebut ke sosial media yang telah dipilih dan diberi keterangan produk secara rinci dan jelas. Tujuannya agar konsumen mengerti tentang suatu produk yang dijual dan konsumen percaya bahwa produk tersebut memang produk yang berkualitas. Setelah produk tersebut diposting, maka womenpreneurs harus selalu mengecek ketersediaan produk dan juga merinci produk-produk yang telah terjual dan menyusun laporan penjualan agar bisnis tetap terarahkan (Anggraeni et al., 2019).

Adapun beberapa yang perlu womenpreneurs tahu untuk menggeluti usaha dengan media sosial yakni diperlukannya pelatihan terkait digital marketing, karena tidak semua pelaku usaha memahami alur dan prosesnya. Penelitian yang dilakukan oleh menyatakan bahwa seluruh responden yang mengikuti pelatihan menemukan beberapa ide baru untuk 
membangun sebuah bisnis dengan modal sosial yakni dengan menggunakan media sosial. Dengan adanya beberapa pelatihan yang dilakukan, maka womenpreneurs akan dengan mudah menghadapi dunia usaha yang penuh dengan competitor (Melissa et al., 2019).

\section{Berwirausaha pada saat pandemi melalui media online}

Organisation for Economic Co-operation and Development (OECD, 2020) melaporkan pandemic Covid-19 berdampak pada perekonomian dalam hal pemasokan maupun permintaan barang dan jasa. Dari sisi pemasokan, perusahaan-perusahan mengalami rantai pasok yang bermasalah, yang kemudian berdampak pada pengurangan bahan baku dan tenaga kerja. Terjadi penurunan tingkat permintaan konsumen terhadap barang maupun jasa dari sisi permintaan. Adapun beberapa kalangan bisnis yang paling terkena dampak pandemic Covid-19 adalah UMKM. UMKM rentan dengan hambatan bisnis karena berkaitan secara langsung dengan bidang usaha yang sangat memerlukan supplier (OECD, 2020).

Tidak hanya bisnis milik wanita biasanya lebih rentan terhadap dampak ekonomi karena usia dan ukuran perusahaan rata-rata yang lebih rendah, tetapi juga mereka terkonsentrasi di sektor industri yang paling terpukul oleh penutupan ekonomi (Kalnins \& Williams, 2014) WE Forum, 2020). Data terbaru dari Global Entrepreneurship Monitor menunjukkan bahwa lebih dari $50 \%$ pengusaha perempuan beroperasi di sektor perdagangan besar/eceran, dibandingkan dengan $42,6 \%$ laki-laki, dan $17,2 \%$ perempuan bekerja di pemerintahan/kesehatan/pendidikan dan layanan sosial dibandingkan dengan $10.1 \%$ laki-laki (Elam et al., 2019). Sektor-sektor ini dicirikan oleh hambatan masuk yang lebih rendah, sangat bergantung pada konsumen sebagai pelanggan (daripada bisnis), dan sangat kompetitif, menjadikannya salah satu yang paling rentan di sebagian besar ekonomi. Selain itu, dengan tidak adanya layanan sekolah, penitipan anak, atau pengasuhan lansia, pengusaha perempuan menanggung sebagian besar beban pengasuhan keluarga (OECD, 2020). Selain itu, perempuan memiliki proporsi pekerjaan rumah yang lebih substansial dibandingkan laki-laki. Ini menciptakan badai yang sempurna bagi pengusaha wanita. Sementara program bantuan bisnis menawarkan beberapa penyangga terhadap guncangan lingkungan, tanggapan kebijakan biasanya diarahkan ke semua pengusaha dan tidak mempertimbangkan gender, yang membuat pengusaha perempuan berjuang sendiri dalam banyak hal (Bradshaw \& Lecturer, 2014).

Singkatnya, pandemi COVID-19 telah menyebabkan tiga tantangan substansial berikut bagi pengusaha perempuan. Pertama adalah industri di mana sebagian besar perempuan beroperasi terpengaruh secara tidak proporsional oleh resesi. Kemudian, wanita lebih cenderung menjalankan banyak bisnis termuda, terkecil, dan paling rentan. Terakhir, dengan sekolah-sekolah ditutup dan anggota keluarga lanjut usia terancam, perempuan lebih mungkin untuk menyulap pengasuhan primer dan pekerjaan rumah tangga sambil berjuang untuk menyelamatkan bisnis mereka. Prospeknya menakutkan, dan pilihan bagi wanita terbatas. Namun, solusi untuk tantangan terkait gender bagi pengusaha perempuan ini dapat mencakup pemotongan biaya dan berputar untuk menangkap peluang bisnis baru yang dihadirkan oleh krisis.

Pandemi Covid-19 juga mengakibatkan perubahan pola konsumtif konsumen. Walaupun telah ada penjualan online, konsumen umumnya akan tetap keluar rumah untuk memenuhi kebutuhan hidupnya. Namun adanya kebijakan PSBB maka masyarakat tidak bisa berlama-lama keluar dari rumah. Berdasarkan hasil observasi penelitian yang dilakukan oleh (Hardilawati, 2020) selama pandemic, UMKM terdampak terutama pada penurunan penjualan. Ini terjadi dikarenakan adanya penurunan kegiatan masyarakat diluar rumah. Alasan kedua yakni kendala transportasi yang berdampak pada sulitnya mendapatkan bahan 
baku. Alasan terakhir ialah menurunnya kepercayaan masyarakat terhadap suatu produk seperti restoran, perhotelan, dan tempat wisata.

Dengan adanya hal tersebut womenpreneurs juga perlu melakukan upaya penyesuaian diri dengan adanya kondisi tersebut dan segera menyusun strategi agar tetap dapat menarik konsumen untuk membeli produk yang dijual. (Hardilawati, 2020) Namun ada beberapa pula UMKM yang tidak mengalami penurunan omset penjualan, dikarenakan UMKM tersebut mampu beradaptasi dan menyesuaikan diri dengan kondisi pandemic. Salah satu strategi yang dilakukan yakni menjual produk dengan menggunakan media sosial. Media sosial yang digunakan para UMKM yakni Instagram, facebook, twitter dan lain sebagainya. Digital marketing memiliki dampak positif dan substansial dalam peningkatan kinerja UMKM. Hal ini dikarenakan digital marketing telah menjadi alat komunikasi paling penting dalam memasarkan produk sedangkan toko offline menjadi pelengkap pada proses jual beli (Hendrawan et al., 2019). Penelitian lain juga menyebutkan bahwa pemasaran produk dengan menggunakan media sosial berupa isntagram mampu menghemat biaya sedangkan impact yang didapatkan tinggi, sehingga bisa menghemat biaya yang dikeluarkan keuntungan yang lain ialah dengan instagram, para pelaku usaha bisa mengakses kapanpun dan dimanapun dengan syarat adanya jaringan internet. Hal ini tentunya juga berlaku bagi konsumen, sehingga konsumen tidak perlu untuk keluar rumah jika ingin membeli produk yang dibutuhkan (Kurniawan, 2017).

Oleh karena hal tersebut womenpreneurs juga harus mampu beradaptasi dengan keadaan pandemi seperti saat ini, agar mampu mempertahankan omset penjualan. Dengan penyusunan strategi digital marketing yang tepat maka proses jual beli akan berjalan seperti sebelumnya. Ini juga akan berdampak pada omset penjualan, semakin baik strategi yang disusun, maka kepercayaan masyarakat terhadap suatu produk juga akan kembali seperti sebelumnya sehingga pola konsumtif masyarakat juga meningkat dan meningkat pula omset penjualan.

\section{SIMPULAN}

Berdasarkan data-data diatas dapat disimpulkan bahwa media sosial sangat bermanfaat bagi keberlangsungan berwirausaha dikalangan perempuan. Adapun proses berwirausaha menggunakan media sosial yakni mulai dari penentuan proses produksi, penentuan media sosial yang akan digunakan, sampai proses pencatatan produk. Media sosial ternyata mampu membuat omset para UMKM tetap stabil di masa pandemic Covid-19 yang terjadi di Indonesia. dengan ketertarikan yang Sama, berbagi informasi secara Real-Time, menjangkau target pasar, peningkatan sirkulasi snformasi. media sosial juga dapat mengalami kerugian seperti, rentan terjadi kesalahpahaman, cyber crime atau kejahatan dunia maya, resiko penipuan atau pencurian identitas, membuang waktu, invasi privasi usaha. Dimana platform media sosial berperan penting dalam memasarkan produk UMKM di masa pandemi COVID-19. Pelaku UMKM belum mengoptimalkan pemasaran produk UMKM melalui media sosial. Beberapa pelaku UMKM sudah menggunakan media sosial untuk pemasaran namun masih dalam skala yang kecil dan belum terorganisir dengan baik. Uji coba optimalisasi pemanfaatan sosial media sebagai sarana pemasaran produk yang baik bagi pelaku UMKM di dapat menaikkan kembali angka penjualan produk UMKM, dan menjangkau konsumen, Pemanfaatan 205 sosial media sebagai sarana penunjang yang efektif bagi berjalanya UMKM di masa pandemi COVID-19 sebab pelaku UMKM masih dapat menjalankan kegiatan usahanya dengan tetap mematuhi dan melaksanakan protokol kesehatan. Hal ini menjadi bukti bahwa media sosial sangat bermanfaat bagi wanita untuk 
berwirausaha di masa pandemi Covid-19. Untuk selanjutnya, perempuan harus lebih memahami pentingnya media sosial dengan dengan bisnis dimasa pandemi.

Saran bagi peneliti yang akan melakukan penelitian selanjutnya, disarankan untuk dapat melanjutkan penelitian yang difokuskan tema promosi menggunakan media sosial. Meskipun demikian, ada kesenjangan dalam literatur untuk memberikan laporan integratif tentang pemanfaatan media sosial untuk berwirausaha di masa pandemi Covid 19.. Untuk menjembatani kesenjangan, ulasan ini literatur memberikan gambaran metode, manfaat, dan tantangan mengenai penggunaan analisis pembelajaran bagi seluruh kalangan. Diharapkan bahwa gambaran yang meningkatkan penerapan media sosial dalam mengembangkan usaha.

\section{REFERENSI}

Anggadwita, G., \& Dhewanto, W. (2016). The influence of personal attitude and social perception on women entrepreneurial intentions in micro and small enterprises in Indonesia. International Journal of Entrepreneurship and Small Business, 27(2-3), 131-148. https://doi.org/10.1504/IJESB.2016.073974

Anggraeni, D., Said, M., \& Febriani, D. (2019). Penggunaan Saluran Komunikasi untuk memenuhi kebutuhan informasi wanita pengusaha kuliner kota depok. 8.

Anugraheni, A. R., Rahmani, A. N., Vionita, V. K., \& Husna, A. N. (2020). Resiliensi pada Wirausahawan Wanita: Studi Literatur. Proceeding of The ..., 94-99.

Astuti, S. D., Waluyo, D. E., \& Subagyo, H. (2020). Pemberdayaan Perempuan Melalui Sekolah Wirausaha Aisyiah Kabupaten Semarang. Abdimasku : Jurnal Pengabdian Masyarakat, 3(1), 71. https://doi.org/10.33633/ja.v3i1.75

Awali, H., \& Rohmah, F. (2020). Urgensi Pemanfaatan E-Marketing Pada Keberlangsungan Umkm Di Kota Pekalongan Di Tengah Dampak Covid-19. BALANCA : Jurnal Ekonomi dan Bisnis Islam, 2(1), 1-14. https://doi.org/10.35905/balanca.v2i1.1342

Bradshaw, S., \& Lecturer, P. (2014). Gender, Development and Disasters Connect With Us Find us on Facebook Read our Blog. 1-2.

Effendi, M., \& Suryana, S. (2019). Women Entrepreneurship Intensions in Indonesia. 65(Icebef 2018), 230-234. https://doi.org/10.2991/icebef-18.2019.54

Elam, A. B., Brush, C. G., Greene, P. G., Baumer, B., Dean, M., \& Heavlow, R. (2019). Global Entrepreneurship Monitor 2018/2019 Women's Entrepreneurship Report. the Global Entrepreneurship Research Association, London Business School, Regents, 8(2).

Hardilawati, W. laura. (2020). Strategi Bertahan UMKM di Tengah Pandemi Covid-19. Jurnal Akuntansi dan Ekonomika, 10(1), 89-98. https://doi.org/10.37859/jae.v10i1.1934

Hendrawan, A., Kuswantoro, F., \& Sucahyawati, H. (2019). Dimensi Kreativitas dan Pengembangan Usaha Mikro Kecil dan Menengah ( UMKM ). Jurnal Hummansi, 2(1), 25-36.

Jha, P., Makkad, M., \& Mittal, S. (2018). Performance-oriented factors for women entrepreneurs - a scale development perspective. Journal of Entrepreneurship in Emerging Economies, 10(2), 329360. https://doi.org/10.1108/JEEE-08-2017-0053

Joesyiana, K. (2019). Penggunaan Media Online Shop dalam Bisnis pada Wirausaha Wanita (Studi Kasus pada Pebisnis Wanita Komunitas Shalihah Preneur melalui Pengelolaan Informasi dengan Media Sosial). Jurnal Valuta, 5(2), 65-80.

Kalnins, A., \& Williams, M. (2014). When do female-owned businesses out-survive male-owned businesses? A disaggregated approach by industry and geography. Journal of Business Venturing, 29(6), 822-835. https://doi.org/10.1016/j.jbusvent.2013.12.001

Kurniawan, P. (2017). Pemanfaatan Media Sosial Instagram Sebagai Komunikasi Pemasaran Modern Pada Batik Burneh Puguh Kurniawan Universitas Trunojoyo Madura. Manajemen Fakultas Ekonomi dan Bisnis Universitas Trunojoyo Madura, 11(2), 219. http://journal.trunojoyo.ac.id/kompetensi/article/view/3533

Kusumadewi, A. N. (2020). Implementasi Jiwa Wirausaha Dan Pemanfaatan Media Sosial Terhadap Minat Berwirausaha Pada Mahasiswi Purwakarta. Eqien: Jurnal Ekonomi dan Bisnis, 7(2), 8794. https://doi.org/10.34308/eqien.v7i2.141

Latipah, I. (2020). Pemberdayaan Perempuan Melalui Pemanfaatan Media Youtube Dalam 
Meningkatkan Keterampilan Wirausaha. Comm-Edu (Community Education Journal), 3(2), 83. https://doi.org/10.22460/comm-edu.v3i2.4150

Lubis, R. L. (2019). Digital Entrepreneurship In Academic Environment : Are We There Yet? Journal of Teaching and Education, 09(01), 167-193. http://www.universitypublications.net/jte/0901/pdf/H9V493.pdf

Melissa, E., Saraswati, M. S., \& Samahita, F. (2019). Pelatihan "Lingkungan Media Sosial Kontemporer: Tantangan Dan Peluangnya" Bagi Perempuan Wirausaha Di Wilayah Jabodetabek. Prosiding Konferensi Nasional Pengabdian Kepada Masyarakat dan Corporate Social Responsibility (PKM-CSR), 2, 138-143. https://doi.org/10.37695/pkmcsr.v2i0.568

Novialumi, A., Affandy, A., \& Narimawati, U. (2020). Perkembangan Media Sosial dalam Merubah Perilaku Women Entrepreneurship Dikota Bekasi. Jurnal Manajemen dan Akuntansi, 15, 188195.

OECD. (2020). Covid-19: SME Policy Responses. Oecd 2020, March, 1-55. https://oecd.dambroadcast.com/pm_7379_119_119680-di6h3qgi4x.pdf

Orser, B., Riding, A., \& Li, Y. (2019). Technology adoption and gender-inclusive entrepreneurship education and training. International Journal of Gender and Entrepreneurship, 11(3), 273-298. https://doi.org/10.1108/IJGE-02-2019-0026

Setini, M., Yasa, N. N. K., Supartha, I. W. G., Giantari, I. G. A. K., \& Rajiani, I. (2020). The passway of women entrepreneurship: Starting from social capital with open innovation, through to knowledge sharing and innovative performance. Journal of Open Innovation: Technology, Market, and Complexity, 6(2). https://doi.org/10.3390/joitmc6020025

Siswanto. (2012). Systematic Review as a Research Method to Synthesize Research Results (Introduction). Buletin Penelitian Sistem Kesehatan, 13(4).

Soetjipto, H. N. (2020). Ketahanan UMKM Jawa Timur. K-Media.

Suyuthi, N. F., Yunus, M. K., Haerani, S., Nursyamsi, I., \& Hamid, N. (2019). Social Capital Capabilities toward IWAPI Business Performance of South Sulawesi Province. Advances in Economics, Business and Management Research (AEBMR), 92(Icame 2018), 119-126. 